Article

\title{
A Molecular Survey of the Diversity of Microbial Communities in Different Amazonian Agricultural Model Systems
}

\author{
Acácio A. Navarrete ${ }^{\dagger}$, Fabiana S. Cannavan ${ }^{\dagger}$, Rodrigo G. Taketani and Siu M. Tsai *
}

Cell and Molecular Biology Laboratory, Centro de Energia Nuclear na Agricultura, Universidade de São Paulo, Av. Centenário-303, CEP. 13.416-000, Piracicaba, SP, Brazil; E-Mails:

navarrete@cena.usp.br (A.A.N.); cannavan@cena.usp.br (F.S.C.); rgtaketani@cena.usp.br (R.G.T.)

$\dagger$ These authors share first authorship.

* Author to whom correspondence should be addressed; E-mail: tsai@cena.usp.br; Tel.: +1-55-19-429-4600 Fax: +1-55-19-429-4610.

Received: 26 March 2010; in revised form: 11 May 2010 / Accepted: 12 May 2010 / Published: 19 May 2010

\begin{abstract}
The processes of land conversion and agricultural intensification are a significant cause of biodiversity loss, with consequent negative effects both on the environment and the sustainability of food production. The anthrosols associated with pre-Colombian settlements in the Amazonian region are examples of how anthropogenic activities may sustain the native populations against harsh tropical environments for human establishment, even without a previous intentionality of anthropic soil formation. In a case study (Model I- "Slash-andBurn") the community structures detected by automated ribosomal intergenic spacer analysis (ARISA) revealed that soil archaeal, bacterial and fungal communities are heterogeneous and each capable of responding differently to environmental characteristics. ARISA data evidenced considerable difference in structure existing between microbial communities in forest and agricultural soils. In a second study (Model II- "Anthropogenic Soil"), the bacterial community structures revealed by terminal restriction fragment length polymorphism (T-RFLP) differed among an Amazonian Dark Earth (ADE), black carbon (BC) and its adjacent non-anthropogenic oxisoil. The bacterial 16S rRNA gene (OTU) richness estimated by pyrosequencing was higher in $\mathrm{ADE}$ than $\mathrm{BC}$. The most abundant bacterial phyla in ADE soils and $\mathrm{BC}$ were Proteobacteria-24\% ADE, 15\% BC; Acidobacteria-10\% ADE, 21\% BC; Actinobacteria-7\% ADE, 12\% BC; Verrucomicrobia, 8\% ADE; 9\% BC; Firmicutes-3\% ADE, 8\% BC. Overall, unclassified bacteria corresponded to $36 \% \mathrm{ADE}$, and $26 \% \mathrm{BC}$. Regardless of current land uses, our data suggest
\end{abstract}


that soil microbial community structures may be strongly influenced by the historical soil management and that anthrosols in Amazonia, of anthropogenic origins, in addition to their capacity of enhancing crop yields, may also improve microbial diversity, with the support of the black carbon, which may sustain a particular and unique habitat for the microbes.

Keywords: microbial diversity; slash-and-burn agriculture; land use systems; Amazonian Dark Earth; Terra Preta de Índio; black carbon

\section{Introduction}

The Brazilian Amazon represents half of the world's rainforest and is home to one-third of the Earth's species, yet the Amazon has one of the highest rates of deforestation due to anthropogenic activities and dramatic changes in land use [1]. Agriculture is one of the largest and most dynamic parts of the Brazilian economy, and those working to preserve the Amazonia biome are unlikely to be able to slow or stop the expansion of this sector. In this post-genomic era, the application of advanced technologies to solve agricultural issues while maintaining environmental quality is of great importance, as the Brazilian economy relies, to a high degree, on crop and food production. Sustainability is one of the main issues that must be considered to develop adequate land use in order to achieve a more sustainable production scheme, particularly under tropical conditions, which are especially conducive to degradation.

Although slash-and-burn agriculture remains a dominant system of food production in the humid and subhumid tropics, it has also become a major cause of deforestation and land degradation [2-4]. Ideally, slash-and-burn agriculture is ecologically stable where there is a very low density of human population. However, such practice rarely exists today except in some remote regions of the Amazon and Congo basins. In a greater part of the humid and subhumid tropics, the fallow period has been reduced and areas cleared for cultivation have become larger. These modifications have led to an eventual breakdown of the slash-and-burn system in the long run because loss of mineral nutrients during the cultivation phase (i.e., through runoff, erosion, leaching, and crop removal) can no longer be restored by short periods of bush fallow [5]. Mosaic landscapes from Western Amazon present systems based on slash-and-burn agriculture. In this region, agricultural systems of indigenous people based primarily on annual crops in shifting cultivation and long fallow, which involves the abandonment of areas coverage with annual cultivation allowing natural regeneration and fallow for approximately three years [6].

Amazonian Dark Earths (ADE) or Terra Preta de Índio of prehistoric origin are differentiated from surrounding soils by their darker color, higher organic matter content, higher $\mathrm{pH}$, greater total phosphorus $(\mathrm{P})$ content, greater exchangeable calcium $(\mathrm{Ca})$ and magnesium $(\mathrm{Mg})$, and increased minor element concentrations [7]. These soils are found in the Amazonian region and are considered as a model soil when compared with the surrounding and background soils. The importance of this soil for agricultural purposes has been discussed thoroughly by soil scientists, archaeologists, geographers, agronomists and anthropologists in 2006, and they all agree that ADE soils were built up by the river basin's original human residents and are much more numerous than formerly appreciated [8]. The 
carbon content in ADE is elevated in comparison with plain soil from nearby locations [9]. The wisdom in building fertile soils under harsh tropical conditions, and maintaining its fertility over centuries, is now considered a wonder that was engineered by pre-Colombian cultures via the addition of pottery shreds, concentrated organic waste, charred biomass, fish bones, shells, various household waste and plant residues.

Molecular methods were used to study the microbial diversity of two agricultural model systems found in Amazonian soils: the slash-and-burn system and the anthrosols. We first characterized the operational taxonomic unit (OTU) richness and the structure of archaeal, bacterial and fungal communities in soils under primary forest, secondary forest, slash-and-burn agriculture and pasture. In the second study, bacterial community from the anthrosols and black carbon were characterized and compared to microbial groups from the neighboring non-anthropogenic soils. These studies used modern genomic approaches in order to assess soil microbial communities in Amazonian ecosystems.

\section{Material and Methods}

Soil was sampled in two Amazonian regions. In the Western Amazon (Model I), samples were taken from areas of undisturbed primary forest, subsistence farms, pastures and secondary forests where slash-and-burn is the main type of agriculture. In the Central Amazon (Model II), samples were taken of anthrosols, also known as Terra Preta de Indio, which are the result of pre-Columbian settlement and are used for sustainable agriculture.

\subsection{Model I: The "Slash-and-Burn" System in Western Amazonia}

\subsubsection{Study sites and soil sampling}

Soil samples were collected from areas located between the geographical coordinates $4^{\circ} 21^{\prime}$ and $4^{\circ} 26^{\prime} \mathrm{S}$ and $69^{\circ} 36^{\prime}$ and $70^{\circ} 1^{\prime} \mathrm{W}$, in the Benjamin Constant municipality and along the Solimões River (Figure 1). The predominant soil class in the studied sites was Inceptisols, but Gleysols and Alisols were also found [10]. The rate of deforestation in this region is quite low, partially due to poor accessibility and the low population density of the region. The native communities use the land for slash-and-burn agriculture; however, some pasture areas are also present as a consequence of governmental polices implemented during the 1970s. Additives, fertilizers or pesticides have not been applied to any of the land-use systems in these studied soils [6].

Twelve soil samples with three replicates each were collected in March 2008 and January 2009, during periods of more intense precipitation than usual in areas of primary forest, local traditional crops, pasture and secondary forest (20-30 years old) using standardized procedures. All sites were originally highland forest. Traditional crops such as cassava, banana, maize, sugarcane and pineapple are grown for the subsistence of native populations. Each soil sample was collected at a depth of 0-20 cm under the litter layer, which was removed prior to sampling, and was submitted to chemical, physical and molecular microbial analyses. 


\subsubsection{DNA extraction and ARISA fingerprinting}

Archaeal, bacterial and fungal communities in the different soils were analyzed using polymerase chain reaction (PCR) and automated ribosomal intergenic spacer analysis (ARISA). DNA was extracted from $0.25 \mathrm{~g}$ (total humid weight) of soil using the Power Soil DNA Isolation Kit (MO BIO Laboratories, Carlsbad, CA, USA), according to the manufacturer's instructions. The DNA extraction was performed in triplicate for each soil sample. The quality and relative quantity of the extracted DNA was determined using a Thermo Scientific NanoDrop 2000. Dilutions of the DNA samples were necessary to eliminate inhibition of PCR by humic acid, as previously described [11].

The archaeal, bacterial and fungal ribosomal intergenic regions (16S-23S for Archaea and Bacteria and 18S-28S for Fungi) were amplified with the primers 915f-FAM and 71r [12], 1490-72f-FAM and LSU21-38r [13] and 2234Cf-FAM and 3126Tr [14], respectively. The forward primer was labeled with 6-FAM (6-carboxifluorescein) at the 5' end. The PCR mixture $(25 \mu \mathrm{L})$ contained $10 \mathrm{ng}$ of template DNA, $2.5 \mu \mathrm{L} 10 \times$ reaction buffer (Invitrogen, Carlsbad, Calif.), $3.0 \mathrm{mM} \mathrm{MgCl} 2,0.2 \mathrm{mM}$ of each dNTP (Eppendorf, Germany), $0.25 \mathrm{mM}$ of each forward (f) and reverse ( $\mathrm{r}$ ) primer (Integrated DNA Technologies, Coralville, IA, USA) and 1.0 U of Platinum Taq DNA Polymerase (Invitrogen). Cycling was performed as described in the references for the primers using a GeneAmp PCR System 9700 Thermal Cycler (Applied Biosystems).

Triplicate PCR products from the soil samples were analyzed using gel electrophoresis and purified using the Qiagen PCR Purification Kit (Qiagen, Valencia, CA, USA). The ARISA-PCR fragments were separated by capillary electrophoresis on ABI Prism 3100 Genetic Analyzer using the size standards GeneScan 120 LIZ (Applied Biosystems), GeneScan 500 ROX (Applied Biosystems) and MegaBACE ET900 (GE Healthcare) for Archaea, Bacteria and Fungi, respectively.

\subsubsection{ARISA Data Analysis}

The ARISA profiles were analyzed using the PeakScanner 1.0 software program (Applied Biosystems). To include the maximum number of peaks while excluding background fluorescence, a threshold of 50 fluorescent units was applied for the archaeal, bacterial and fungal data. The software converted the fluorescence data into electropherograms; the peaks represent fragments of different sizes, and the peak areas represent the relative proportion of these fragments. The number of peaks in each electropherogram was interpreted as the OTU richness in the community.

To investigate which soil attributes best explained the variability in ARISA profiles, a Non-metric multidimensional scaling (NMDS) was performed in Canoco 4.5 (Biometrics, Wageningen) with Hellinger transformed data [15]. This multivariate analysis was supplemented with environmental data. Five soil attributes were included in this analysis - $\mathrm{pH}$, organic matter $(\mathrm{OM}), \mathrm{Fe}, \mathrm{K}$, and $\mathrm{P}$. Analysis of similarities (ANOSIM) was performed with the Primer5 5.2.6 (Plymouth Marine Laboratory, Primer-E) software program. 


\subsection{Model II: The Amazonian Dark Earth and Sustainable Agriculture in the Central Amazon}

\subsubsection{Soil sample collection}

Soil samples were collected from the Hatahara site, a well-documented anthrosol characterized as Amazonian Dark Earth (ADE). Another set of non-anthropogenic soil samples were collected at vicinity (ADJ). Three different points (10 m apart) were sampled at each site. Samples were immediately frozen and kept at $-20.0^{\circ} \mathrm{C}$ until their use. Hatahara is located within the Amazon basin near Iranduba-Manaus, Brazil (ADE soil 03¹6'28.45"S; 60¹2'17.14"W and ADJ soil 03¹6'24.43"S; $60^{\circ} 11^{\prime} 58.74^{\prime \prime} \mathrm{W}$ ), and the soil in this site has been dated to be between 300 B.C. (first human occupation) and 1200 A.C. This site includes one of the most archaeological sites studied by archaeologists and geologists to the characterization of ADE. Therefore, the sampling area has not been disturbed for more than 10 years.

The natural vegetation of these regions is described as tropical lowland rainforest. At Hatahara site, the samples were collected from soil under passion fruit cultivation; Lithic fragments and ceramic artifacts were present in soils, indicating pre-Columbian occupation. The soil characteristics that were consistently different between the adjacent and anthropic soils were the black carbon (BC) content, the dark color and the presence of ceramic fragments in the anthrosols. The influence of $\mathrm{BC}$ on the soil microbial community was also investigated. Soil samples were taken with a sterilized plastic tube $5 \mathrm{~cm}$ diameter and $10 \mathrm{~cm}$ length at a $0-20 \mathrm{~cm}$ depth discarding the overlaying litter.

\subsubsection{DNA Extraction and PCR amplification to T-RFLP analysis}

The same protocol used for DNA extraction from the Western Amazonian soils was followed for DNA extraction from the ADE and ADJ soils and the separated BC. The BC separation was carefully performed under sterile conditions at $4{ }^{\circ} \mathrm{C}$, using a magnifier to facilitate screening of the black carbon from the soil. Whole community DNA was extracted from three replicate sub-samples. Total DNA was extracted from $0.25 \mathrm{~g}$ (fresh weight) of each sample using the Power Soil DNA Isolation Kit (MO BIO Laboratories), according to the manufacturer's instructions. Reactions were performed in triplicate for each soil sample. The quality and relative quantity of the extracted DNA was determined by using a Thermo Scientific NanoDrop 2000.

For the Terminal Restriction Length Polymorphism (T-RFLP) analysis, the bacterial 16S rRNA gene was amplified with the primers $27 \mathrm{~F}$ (5'end labeled with FAM fluorescent dye) and 1492R [16,17]. The PCR mixture $(25 \mu \mathrm{L})$ contained $10 \mathrm{ng}$ of template DNA, $2.5 \mu \mathrm{L} 10 \times$ reaction buffer (Invitrogen, Carlsbad, Calif.), $3.0 \mathrm{mM} \mathrm{MgCl}_{2}, 0.2 \mathrm{mM}$ of each dNTP (Eppendorf, Germany), $0.25 \mathrm{mM}$ of each forward (f) and reverse (r) primer (Integrated DNA Technologies, Coralville, IA, USA) and $1.0 \mathrm{U}$ of Platinum Taq DNA Polymerase (Invitrogen). Cycling was performed as follows: 3 min at $94{ }^{\circ} \mathrm{C}$, followed by 35 cycles of $94{ }^{\circ} \mathrm{C}$ for $30 \mathrm{~s}, 59{ }^{\circ} \mathrm{C}$ for $45 \mathrm{~s}, 72{ }^{\circ} \mathrm{C}$ for $1 \mathrm{~min}$, and a final extension step at $72{ }^{\circ} \mathrm{C}$ for $15 \mathrm{~min}$, using a GeneAmp PCR System 9700 Thermal Cycler (Applied Biosystems).

Triplicate PCR products for soil samples were analyzed by gel electrophoresis and purified with the Qiagen PCR purification kit (Qiagen, Valencia, CA, USA). PCR products (60 ng) were digested with the enzymes MspI and HhaI (Invitrogen, USA) in $20 \mu \mathrm{L}$ separate reactions, at $37^{\circ} \mathrm{C}$ for $3 \mathrm{~h}$. The DNA 
was precipitated using isopropanol [18]. The DNA pellets were resuspended in $9.8 \mu \mathrm{L}$ de deionized formamide and $0.2 \mu \mathrm{L}$ of GeneScan-500 ROX internal size standard (Applied Biosystems, USA) and denatured at $94{ }^{\circ} \mathrm{C}$ for $5 \mathrm{~min}$ and immediately transferred onto ice. Fragments were analyzed in an ABI 3100 automated sequencer (Applied Biosystems) following manufacturer's instructions.

The size and intensity of each T-RF (hereafter called phylotype) was estimated using Peak Scanner Software v1.0 (Applied Biosystems). The peaks represent fragments of different sizes, and the peak areas represent the relative proportion of these fragments. The number of peaks in each electropherogram was interpreted as the OTU richness in the community. A redundancy analysis (RDA) was performed with the package vegan BiodiversityR [19] for the program $\mathrm{R}$ [20] with Hellinger transformed data. RDA is an ordination technique that seeks the most prominent linear gradients in multivariate data sets, under the constraint that the gradients are linear combinations of a set of explanatory variables. Two soil attributes were included in this analysis after stepwise selection (inflation factor $<10$ ) — organic matter $(\mathrm{OM})$ and $\mathrm{P}$.

\subsubsection{Pyrosequencing of the $16 \mathrm{~S}$ rRNA gene isolated from ADE and black carbon}

Sequencing of the ADE and BC from Hatahara was performed using the Genome Sequencer FLX System (454 Life Sciences, Bradford, CT, USA) at the Center for Microbial Ecology, Michigan State University. The primers that were used targeted the V4 region of the 16S rRNA gene (http://pyro.cme.msu.edu/). PCR reactions contained $0.015 \mathrm{U} / \mu \mathrm{L}$ Taq DNA polymerase, $1 \times$ reaction buffer, $1.8 \mathrm{mM} \mathrm{MgCl}$, $0.2 \mathrm{mM}$ of each dNTP, $0.2 \mu \mathrm{M}$ of each primer (Integrated DNA Technology), $1.5 \times \mathrm{BSA}, 4 \mathrm{ng} / \mu \mathrm{L}$ of template and 1 unit of FastStart High Fidelity PCR System enzyme blend (Roche Applied Science, Indianapolis, IN). The following cycle parameters were used: initial denaturation for $3 \mathrm{~min}$ at $95{ }^{\circ} \mathrm{C} ; 30$ cycles of $45 \mathrm{~s}$ at $95{ }^{\circ} \mathrm{C}, 45 \mathrm{~s}$ at $57^{\circ} \mathrm{C}$ and $1 \mathrm{~min}$ at $72{ }^{\circ} \mathrm{C}$; and final extension for $4 \mathrm{~min}$ at $72{ }^{\circ} \mathrm{C}$. The PCR products were separated by gel electrophoresis, and fragments with size in the range of 270-300 bp were excised and extracted by using the Qiagen Gel Extraction Kit (Qiagen, Valencia, CA). Further purification was performed with the Qiagen PCR Purification Kit (Qiagen). Sequencing was performed by using a GS FLX sequencer (454 Life Sciences) at the Michigan State University Research Technology Support Facility. Sequences were analyzed using the RDP pipeline [21,22]. A rarefaction curve was generated by using MOTHUR [23] to estimate OTU richness (cut-off 0.03).

\section{Results and Discussion}

\subsection{Model I of Amazonian Agricultural System: The "Slash-and-Burn" System in Western Amazonia}

This survey was undertaken in a region of Western Amazonia in the basin of Alto Solimões. The territory is similar to the land of the indigenous people who established their subsistence agriculture. Soil samples were collected over a two-year sampling in areas characterized by tropical rainforest, semi-permanent manioc cultivation with slash-and-burn agricultural management, pasture and forested areas at advanced stages of regeneration. The archaeal, bacterial and fungal communities were analyzed by ARISA, and their OTU richness was represented graphically in Figure 1. 
Figure 1. Operational taxonomic unit richness based on intergenic spacer region length polymorphisms of the rRNA gene detected using automated ribosomal intergenic spacer analysis (ARISA). The maps show the four sampling windows located in an Amazonian landscape (Benjamin Constant municipality, Amazonas State, Brazil, along the Solimões River). The colors represent different land use systems: primary forest $(\square)$, secondary forest $(\square)$, crops $(\square)$, pasture $(\square)$, water $(\square)$ and exposed soil $(\square)$. Soil samples were collected at different points (*), at a depth of 0-20 cm from sites representing primary tropical rain forest, traditional crops systems of the indigenous people, pasture and secondary forest over a two-year sampling (March 2008 and January 2009). The richness values were calculated based on triplicate PCR products from the soil samples.

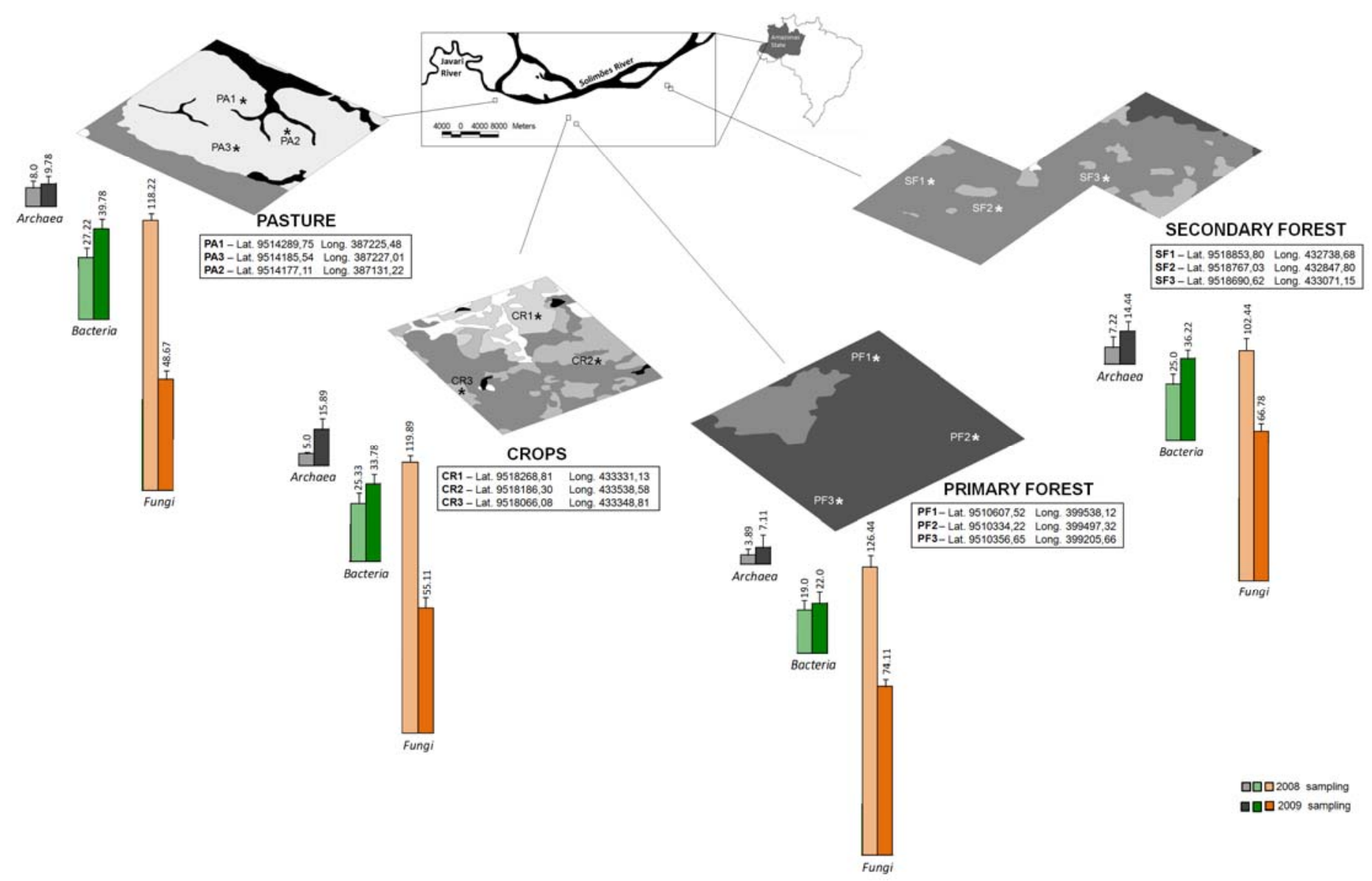


Based on ARISA data, differences in archaeal, bacterial and fungal OTU richness were observed in the March 2008 and January 2009 samples. In 2008 sampling, the archaeal OTU richness was higher in pasture soil (8.0) followed by lower richness in secondary forest soil (7.22), crop soil (5.0) and primary forest soil (3.89). In 2009 sampling, lower archaeal richness was found in crop soil (15.89), in comparison with secondary forest (14.44), pasture (9.78) and primary forest (7.11) soils. In the two-years sampling less archaeal richness in primary forest soil was found. Although there are some reports addressing the archaeal diversity in tropical climatic zones [24-26], the understanding of these communities and their roles in ecosystems is incipient. Our study represents the initial effort to understand the archaeal communities present in tropical soils under different land use systems.

Soil bacterial OTU richness was higher in pasture in the two-years sampling (27.22 and 39.78, respectively) and less in primary forest soil (19.0 and 22.0, respectively). In crop, soil bacterial OTU richness was found similar to that of secondary forest. A previous study examining the same sampling areas from the Western Amazon [27] reported similarity between the primary and secondary forest bacterial communities, suggesting that the bacterial community structure recovered during forest regeneration.

Studies on fungal diversity in tropical soils have concluded that the cultivation soil can alter the abundance of some members of the soil fungal community [28-30]. However, soil fungal communities have recovered relatively quickly after fallow [31]. These investigations showed that the impact of deforestation and slash-and-burn in the soil fungal community is more quantitative than qualitative. In our study, the fungal OTU richness was higher in primary forest soil in two-years sampling in comparison with secondary forest, crops and pasture. In crops and pasture, the soil fungal communities presented a higher richness than secondary forest soil.

Although total richness levels are difficult to estimate with a high degree of confidence, the estimated fungal OTU number by ARISA technique appears to rival or exceed the number of archaeal and bacterial OTUs in each of the collected soils. A possible explanation for the fungal OTU number detected by ARISA technique is the higher variation in the 18S-28S rRNA intergenic spacer region in eukaryotes [32] which must have led to this apparent higher diversity of the fungi. Archaeal and bacterial OTU richness detected by ARISA were higher in soil samples collected in January 2009, whereas, for fungi, it was higher in the soil samples collected in March 2008.

No significant differences were noted between land use systems for soil attributes $(\mathrm{p}<0.05)$ in the two-years sampling in the Benjamin Constant municipality (Table 1). The soil $\mathrm{pH}$ in the forests was lower than at sites under slash-and-burn agricultural management or pasture. The organic matter (OM) content in soil from the semi-permanent manioc cultivation sites and secondary forests was higher than in soil samples from primary forest or pasture sites. The soils presented $17-38 \%$ sand, $36-53 \%$ silt and 25-35\% clay at all sites. The deforestation of tropical forests alters many soil properties. Previous studies have shown that conversion to pasture causes an increase in $\mathrm{pH}$ and soil bulk density as well as a decrease in soil porosity [33-35]. As seen in Table 1, the Amazonian soils also have undergone a similar transformation. In slash-and-burn agriculture, soil attributes change as a consequence of ash deposition from the burned vegetation and increased rates of organic matter decomposition [5]. Over time, however, nutrients are depleted, and these attributes tend to return to their previous state.

Soil phosphorous showed discrepant values in soil samples collected in March 2008 and January 2009. Agricultural management can affect soil organic matter chemistry and microbial community 
structure, but the relationship between the two is not well understood [36]. The origin and mineralization processes of soil organic $\mathrm{P}$ are less well understood [37]. Fungi tend to contain a significant proportion of their total $\mathrm{P}$ content in inorganic forms, i.e., as orthophosphate or as polyphosphates. However, based on the results by Makarov et al. [37], differences in the microbial community composition may also influence the chemical composition of organic $\mathrm{P}$ in soil.

Table 1. Chemical and physical attributes of soil samples from different land use systems in Benjamin Constant municipality.

\begin{tabular}{|c|c|c|c|c|c|c|c|c|}
\hline \multirow{3}{*}{ Attributes } & \multicolumn{8}{|c|}{ Land Use } \\
\hline & \multicolumn{2}{|c|}{ Primary forest* } & \multicolumn{2}{|c|}{ Secondary forest* } & \multicolumn{2}{|c|}{ Crops* } & \multicolumn{2}{|c|}{ Pasture* } \\
\hline & 2008 & 2009 & 2008 & 2009 & 2008 & 2009 & 2008 & 2009 \\
\hline \multicolumn{9}{|l|}{ Chemical } \\
\hline $\mathrm{pH}\left(\mathrm{CaCl}_{2}\right)$ & $4.0 \pm 0.4$ & $4.1 \pm 0.2$ & $3.9 \pm 0.05$ & $4.0 \pm 0.3$ & $4.8 \pm 0.8$ & $4.4 \pm 0.6$ & $4.5 \pm 0.6$ & $3.88 \pm 0.1$ \\
\hline $\mathrm{OM}\left(\mathrm{g} \cdot \mathrm{dm}^{-3}\right)$ & $29.0 \pm 14.7$ & $32.3 \pm 5.2$ & $34.7 \pm 20.3$ & $26.3 \pm 3.9$ & $39.3 \pm 15.5$ & $25.7 \pm 2.9$ & $27.3 \pm 9.2$ & $31.3 \pm 5.5$ \\
\hline $\mathrm{Fe}\left(\mathrm{mg} \cdot \mathrm{dm}^{-3}\right)$ & $159.7 \pm 17.1$ & $93 \pm 8.2$ & $109.3 \pm 30.1$ & $69.7 \pm 18.6$ & $55.0 \pm 10.8$ & $74.7 \pm 13.7$ & $66.3 \pm 13.0$ & $147.3 \pm 21.2$ \\
\hline $\mathrm{P}\left(\mathrm{mg} \cdot \mathrm{dm}^{-3}\right)$ & $9.7 \pm 1.1$ & $11.0 \pm 2.0$ & $8.0 \pm 1.4$ & $6.0 \pm 1.0$ & $1.9 \pm 0.8$ & $9.3 \pm 1.1$ & $6.0 \pm 0.8$ & $6.7 \pm 0.7$ \\
\hline $\mathrm{K}\left(\mathrm{mmolc} \cdot \mathrm{dm}^{-3}\right)$ & $1.4 \pm 0.5$ & $1.3 \pm 0.1$ & $1.7 \pm 0.5$ & $1.2 \pm 0.5$ & $1.9 \pm 0.9$ & $2.1 \pm 0.8$ & $2.1 \pm 0.3$ & $1.6 \pm 0.9$ \\
\hline \multicolumn{9}{|l|}{ Physical } \\
\hline Clay (\%) & $31.0 \pm 7.6$ & $35.7 \pm 6.1$ & $35.5 \pm 12.7$ & $36.0 \pm 12.3$ & $25.8 \pm 2.6$ & $22.3 \pm 7.5$ & $25.4 \pm 6.3$ & $27.7 \pm 9.4$ \\
\hline Silt (\%) & $51.7 \pm 1.9$ & $47.7 \pm 3.4$ & $45.8 \pm 6.5$ & $43.7 \pm 3.2$ & $53.6 \pm 7.3$ & $41.3 \pm 2.5$ & $36.6 \pm 11.0$ & $37.7 \pm 1.8$ \\
\hline Sand $(\%)$ & $17.3 \pm 5.7$ & $16.7 \pm 4.9$ & $18.7 \pm 13.4$ & $20.3 \pm 9.5$ & $20.6 \pm 4.7$ & $36.3 \pm 3.1$ & $38.0 \pm 16.6$ & $34.7 \pm 2.2$ \\
\hline
\end{tabular}

The values are average based on triplicate of sampling point in each land-use system. Standard deviations were shown in the table.

*No significant differences between land use systems for soil attributes $(p<0.05)$ in the two-years sampling.

Differences in archaeal, bacterial and fungal community structures were observed in the March 2008 and January 2009 samples. This observation was further supported by results from the multivariate analysis. NMDS analysis of our data sets supplemented with the soil attributes indicated that the first axis was highly correlated with the microbial community structure-soil attribute data (Figure 2; Table 2). Moreover, the second axis showed the same degree of correlation, suggesting that these data sets were governed by more than one gradient. Temporal variability in the composition of soil archaeal, bacterial and fungal communities may complicate the interpretation of spatial patterns of microbial community structure in relation to the soil properties associated with different land use systems. However, in general, archaeal, bacterial and fungal communities formed groups in function of the land use systems in the two-years sampling, except for the fungal communities based on March 2008 samples. Based on the pairwise R statistic from ANOSIM procedure, most of the interactions between the microbial community structures accessed by ARISA formed distinct groups $(\mathrm{R}>0.50)$. The interactions between the fungal communities structure from March 2008 samples had lower $\mathrm{R}$ values $(\mathrm{R}<0.03)$ (Table 2; Figure 2). 
Figure 2. Non-metric multidimensional scaling (NMDS) analysis of sampling points based on the structure of soil archaeal, bacterial and fungal communities as determined by automated ribosomal intergenic spacer analysis (ARISA) and soil attributes. Samples were collected in March 2008 and January 2009. Each vector points to the direction of increase for a given variable and its length indicates the strength of the correlation between the variable and the ordination scores. The colors represent different land use systems: Primary Forest (PF, $\square)$; Secondary Forest (SF, ๑); Crops (CR, $\diamond)$; Pasture (PA, $\boldsymbol{\nabla})$. Each point in the ordination is identified by the abbreviation of the correspondent land use system followed by the point sampling (1, 2 and 3) and replicate PCR product analyzed (A, B and C).

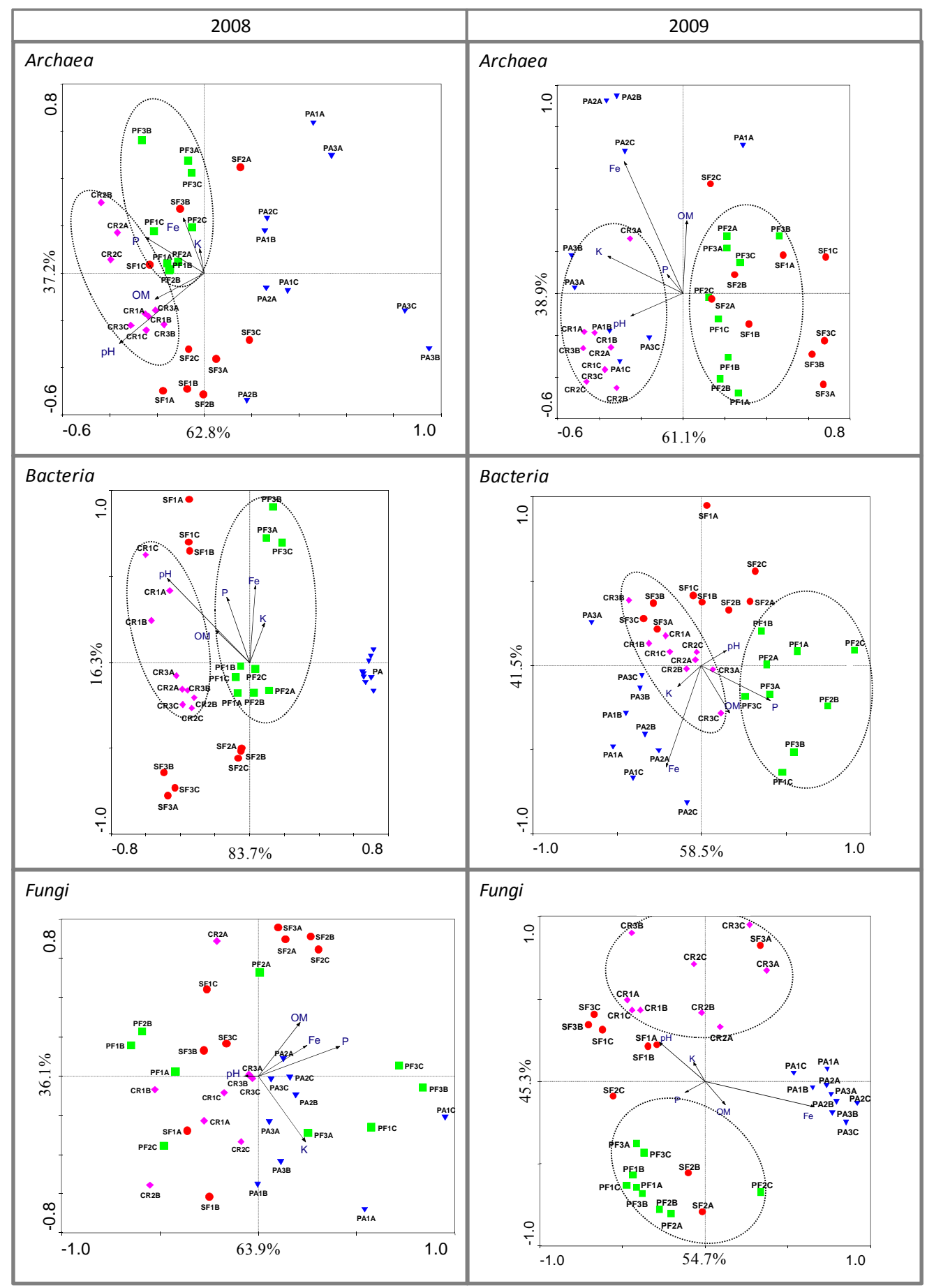


Table 2. Description of the non-metric multidimensional scaling (NMDS) and analysis of similarities (ANOSIM).

\begin{tabular}{|c|c|c|c|c|c|c|c|c|c|}
\hline & \multicolumn{6}{|c|}{ NMDS } & \multirow{3}{*}{ Interactions ${ }^{\mathrm{d}}$} & \multirow{2}{*}{\multicolumn{2}{|c|}{ ANOSIM }} \\
\hline & Stress $^{\mathrm{a}}$ & $\begin{array}{c}\text { Correlation } \\
(\%)\end{array}$ & $\begin{array}{c}\text { Variability }^{\mathrm{c}} \\
(\%)\end{array}$ & Stress $^{\mathrm{a}}$ & $\begin{array}{c}\text { Correlation } \\
(\%)\end{array}$ & $\begin{array}{c}\text { Variability }^{\mathrm{c}} \\
(\%)\end{array}$ & & & \\
\hline & \multicolumn{3}{|c|}{2008} & \multicolumn{3}{|c|}{2009} & & 2008 & 2009 \\
\hline Archaea & 0.021 & 62.8 & 43.0 & 0.031 & 61.1 & 63.5 & $\begin{array}{l}\text { CR,PF } \\
\text { PA,PF } \\
\text { SF,PF }\end{array}$ & $\begin{array}{l}0.275 \\
0.725 \\
0.300\end{array}$ & $\begin{array}{l}0.881 \\
0.616 \\
0.152\end{array}$ \\
\hline Bacteria & 0.028 & 83.7 & 75.5 & 0.022 & 58.5 & 58.5 & $\begin{array}{l}\text { CR,PF } \\
\text { PA,PF } \\
\text { SF,PF }\end{array}$ & $\begin{array}{l}0.448 \\
0.985 \\
0.270\end{array}$ & $\begin{array}{l}0.642 \\
0.701 \\
0.601\end{array}$ \\
\hline Fungi & 0.039 & 63.9 & 75.5 & 0.019 & 54.7 & 83.7 & $\begin{array}{l}\text { CR,PF } \\
\text { PA,PF } \\
\text { SF,PF }\end{array}$ & $\begin{array}{l}0.221 \\
0.057 \\
0.218\end{array}$ & $\begin{array}{l}0.762 \\
0.983 \\
0.579\end{array}$ \\
\hline
\end{tabular}

\footnotetext{
${ }^{a}$ Indicates the fidelity of the regression used in the analysis (100 permutations).

${ }^{\mathrm{b}}$ Indicates the microbial community structure-soil attribute correlations for the first axis.

${ }^{\mathrm{c}}$ Percentage of variability in species data explained by the first axis.

${ }^{\mathrm{d}}$ PF, Primary Forest; CR, Crops; PA, Pasture; SF, Secondary Forest
}

By observing the organization of the microbial community in relation to soil attributes we can begin to generate and test hypotheses regarding the rules which govern the distribution of microorganisms in the different land use systems. In this case, the data obtained by ARISA technique when analyzed together with soil attributes show that soil archaeal, bacterial and fungal communities are heterogeneous entities with distinct components that are each capable of responding differently to environmental characteristics. Pasture microbial communities were clearly separated from others land use systems and are related to higher Fe concentrations detected in soil samples collected in January 2009 , for example.

In the ordinations, a gradient can be noted in which microbial community structures from primary forest soil are distinct from those in soil under crops (circled groups on Figure 2). In this sense, our results are consistent with studies in nontropical areas, in which the structure of microbial communities in the soil over two years in a series of replicated plots was investigated. The studied area included cultivated fields, fields abandoned from cultivation and fields with no history of cultivation, in sites established in 1989 to study ecological processes in agro-ecosystems in the state of Michigan [38]. These authors showed that fields with no history of cultivation differed significantly from cultivated fields. When comparing abandoned fields (where cultivation had ceased), only the field abandoned 45 years ago presented a microbial community structure comparable to those from fields with no history of cultivation. Anthropogenic activities, including agricultural land management practices, directly and indirectly affect soil environments and thus may also alter the activity and diversity of soil microbial communities [39-45].

Selection of primers used for amplification of the intergenic spacer region of the rRNA gene of Archaea, Bacteria and Fungi will affect the outcome of studies examining microbial community structure. In Model I of this study, we concentrated on analysis of the amplified intergenic spacer of the rRNA gene, as have other researchers [46-49], because of greater variability in amplified intergenic spacer than 16S rRNA. The relative conservation of the 16S rRNA may not identify all the variation in microbial community structure, such as certain species-level variation [46]. 
3.2. Model II of an Amazonian Agricultural System: Bacterial Community Structure in Amazonian Dark Earth (ADE) and Black Carbon (BC)

Significant differences were noted between ADE and ADJ soil for soil attributes $(p<0.05)$. The chemical analysis (Table 3) of soil samples ADE and ADJ Hatahara site revealed ADE soil pH higher than in ADJ soil. Similar results were obtained by Lima et al. (2002) [50] and Falcão and Borges (2006) [51]. In ADE, soil was noted high Ca and P content, high cation exchange capacity (CEC) and low Al saturation in comparison with ADJ soil. Lehmann et al. (2003) [52] observed high Ca and P content in ADE from other sites. The high CEC values are due to high organic matter content and density of charges per unit of carbon [53]. This property of organic carbon is specific to soils with high content of black carbon as ADE soil [54]. Altogether, these chemical properties are responsible for the quality and fertility of ADE soils [52].

The ADE has been conceived as a major example of sustainable agriculture because, since their initial description, these soils have been recognized as one of the most fertile soils known, even after extensive crop use [8]. Its potential surpasses the use for the sustainable growing of food and fuel and has implications even in carbon sequestration [8]. Therefore, comprehending how the microbial community is structured in such environments is key to a better management of this resource.

Table 3. Chemical attributes of ADE and ADJ soil samples.

\begin{tabular}{lcc}
\hline \multirow{2}{*}{ Attributes } & \multicolumn{2}{c}{ Hatahara } \\
\cline { 2 - 3 } & ADE & ADJ \\
\hline $\mathrm{pH}\left(\mathrm{CaCl}_{2}\right)$ & $5.2 \pm 0.2 \mathrm{a}$ & $3.7 \pm 0.11 \mathrm{~b}$ \\
$\mathrm{OM}\left(\mathrm{g} \cdot \mathrm{dm}^{-3}\right)$ & $53 \pm 2.64 \mathrm{a}$ & $33.3 \pm 1.15 \mathrm{~b}$ \\
$\mathrm{P}\left(\mathrm{mg} \cdot \mathrm{dm}^{-3}\right)$ & $508.7 \pm 45.5 \mathrm{a}$ & $7.3 \pm 1.15 \mathrm{~b}$ \\
$\mathrm{~S}\left(\mathrm{mg} \cdot \mathrm{dm}^{-3}\right)$ & $4.3 \pm 0.57 \mathrm{a}$ & $3.6 \pm 0.57 \mathrm{~b}$ \\
$\mathrm{~K}\left(\mathrm{mmolc} \cdot \mathrm{dm}^{-3}\right)$ & $1.1 \pm 0.25 \mathrm{a}$ & $0.6 \pm 0.05 \mathrm{~b}$ \\
$\mathrm{Ca}\left(\mathrm{mmolc}_{\mathrm{dm}} \mathrm{dm}^{-3}\right)$ & $138.3 \pm 7.63 \mathrm{a}$ & $6.3 \pm 1.15 \mathrm{~b}$ \\
$\mathrm{Mg}\left(\mathrm{mmolc}_{\mathrm{dm}}{ }^{-3}\right)$ & $13.7 \pm 3.05 \mathrm{a}$ & $1 \pm 0 \mathrm{~b}$ \\
$\mathrm{Al}\left(\mathrm{mmolc} . \mathrm{dm}^{-3}\right)$ & $0 \pm 0 \mathrm{a}$ & $14 \pm 1.73 \mathrm{~b}$ \\
$\mathrm{H}+\mathrm{Al}\left(\mathrm{mmolc}_{\mathrm{dm}}{ }^{-3}\right)$ & $48.7 \pm 5.77 \mathrm{a}$ & $95.7 \pm 14.6 \mathrm{~b}$ \\
$\mathrm{SB}\left(\mathrm{mmolc} \cdot \mathrm{dm}^{-3}\right)$ & $153.7 \pm 5.39 \mathrm{a}$ & $8 \pm 1.12 \mathrm{~b}$ \\
$\mathrm{CEC}\left(\mathrm{mmolc} \cdot \mathrm{dm}^{-3}\right)$ & $201.7 \pm 2.25 \mathrm{a}$ & $103 \pm 615.7 \mathrm{~b}$ \\
$\mathrm{BS}(\%)$ & $76 \pm 2.64 \mathrm{a}$ & $7.7 \pm 0.57 \mathrm{~b}$ \\
\hline
\end{tabular}

Average values based on triplicates of each soil. Standard deviations are shown in the table. Different letters indicates a significant differences (ANOVA followed by Tukey test $p \leq 0,05$ ). $\mathrm{SB}=\mathrm{Sum}$ of Base; $\mathrm{CEC}=$ Cation Exchange Capacity; BS $=$ Base Saturation.

Bacterial fingerprints of the most dominant populations present in $\mathrm{ADE}$ and $\mathrm{ADJ}$ soil and $\mathrm{BC}$ were obtained by T-RFLP analysis. RDA of the T-RFLP profiles showed that some bacterial communities differed in structure and that these differences are related especially those linked to phosphorus (Figure 3). The difference revealed in the bacterial community structure in this study by T-RFLP were similar to those indicated by [55] and [56] despite their similar below-ground bacterial community.

In Redundancy Analysis (RDA) (Figure 3), specifically the ordination based on T-RFs profiles obtained with the enzyme MspI, the bacterial community structure formed separate groups from ADE 
and $\mathrm{ADJ}$ soil and $\mathrm{BC}$. On the other hand, the ordination based on bacterial community structures obtained with the enzyme HhaI did not separate ADE soil and BC, but it separated ADJ soil in this group. This analysis showed that differences in the soil bacterial community structure were related soil attributes, such as $\mathrm{P}$ and organic matter (enzyme HhaI data) and P (enzyme MspI data).

Figure 3. Redundancy Analysis (RDA) of ADE ( $\square$ ) and ADJ (•) soil and BC ( $\bullet$ based on the structure of soil bacterial community as determined by terminal restriction fragment length polymorphism (T-RFLP) and soil attributes. The ordinations were performed using data obtained with the enzymes MspI and HhaI.

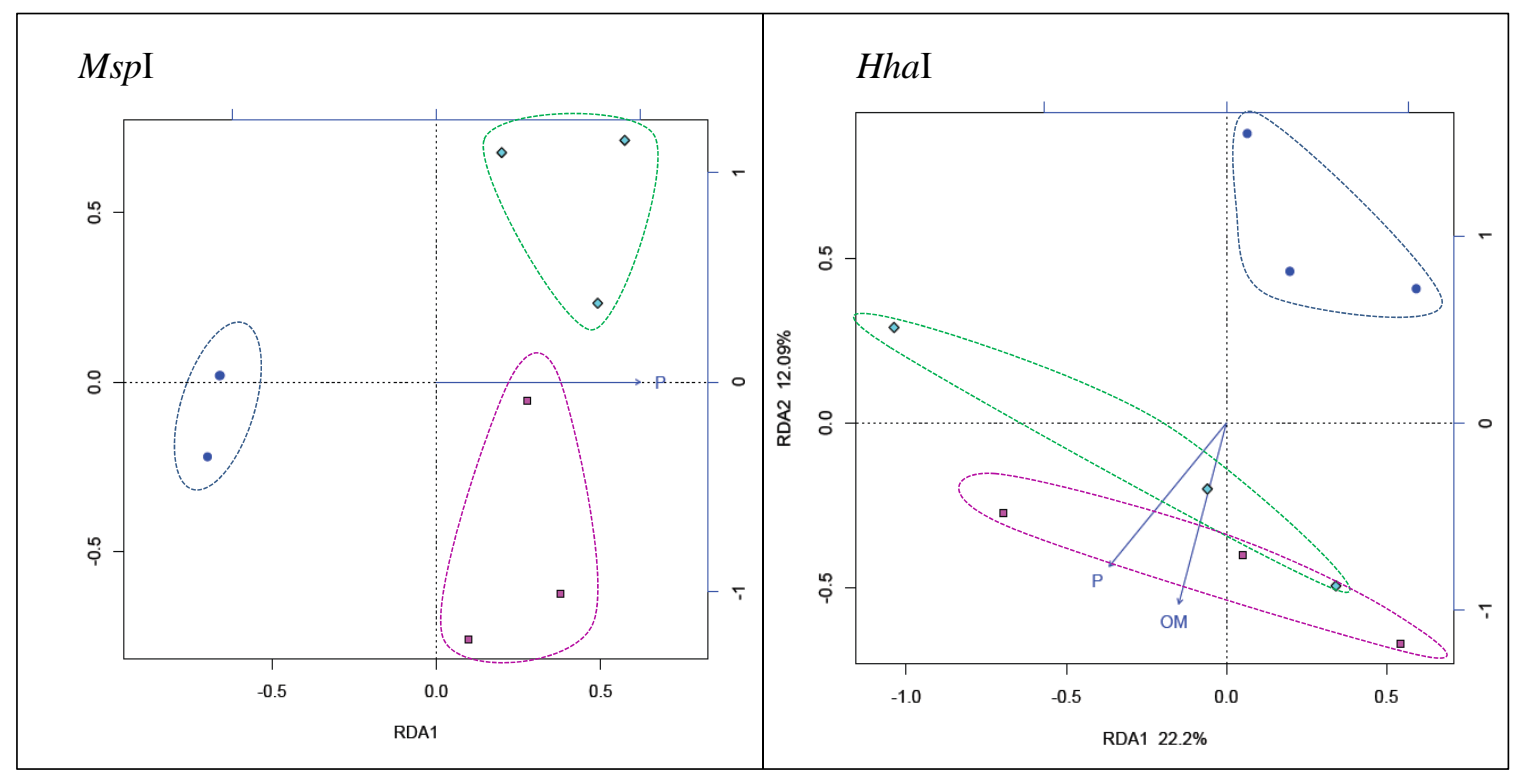

The T-RF number and abundance were initially used to calculate diversity measures (Table 4). The diversity measures presented variation based on sample (ADE, ADJ and BC) and enzymes (MspI and HhaI). Considering the enzyme MspI, we observed higher diversity on ADE soil $\left(\mathrm{H}^{\prime}=4.15 \pm 0.09\right)$ and the lower diversity was noted on $\mathrm{ADJ}\left(\mathrm{H}^{\prime}=3.10 \pm 0.52\right)$. In contrast, the enzyme HhaI data revealed higher diversity on ADJ soil $\left(\mathrm{H}^{\prime}=2.09 \pm 0.31\right)$ and lower diversity on ADE soil $\left(\mathrm{H}^{\prime}=1.84 \pm 0.64\right)$. Subtle differences were noted in the evenness of bacterial community.

Table 4. Diversity index and richness estimation of T-RFs for ADE and ADJ soil and BC based on enzymes MspI and HhaI data.

\begin{tabular}{|c|c|c|c|c|c|c|}
\hline \multirow{2}{*}{$\begin{array}{c}\text { Sample } \\
\quad \mathrm{s}\end{array}$} & \multicolumn{2}{|c|}{ T-RFs Richness } & \multicolumn{2}{|c|}{ Evenness } & \multicolumn{2}{|c|}{$H^{\prime}\left(\log _{e}\right)$} \\
\hline & MspI & HhaI & MspI & HhaI & MspI & HhaI \\
\hline $\mathrm{ADE}$ & $100 \pm 15.7$ & $10.3 \pm 5$ & $0.90 \pm 0.01$ & $0.80 \pm 0.09$ & $4.15 \pm 0.09$ & $1.84 \pm 0.64$ \\
\hline ADJ & $42.6 \pm 20.5$ & $11.6 \pm 3$ & $0.84 \pm 0.02$ & $0.85 \pm 0.06$ & $3.10 \pm 0.52$ & $2.09 \pm 0.31$ \\
\hline $\mathrm{BC}$ & $56.3 \pm 9.8$ & $20.3 \pm 24$ & $0.82 \pm 0.08$ & $0.81 \pm 0.09$ & $3.33 \pm 0.39$ & $1.99 \pm 0.68$ \\
\hline
\end{tabular}


It is considered that high levels of carbon (BC) enhance soil fertility by retaining nutrients and water and increasing the $\mathrm{pH}[54,57]$. Additionally, the surface charge properties of $\mathrm{BC}$ are thought to increase the cation exchange capacity, thereby reducing nutrient leaching [53]. On the other hand, little is known about the contribution of $\mathrm{BC}$ as a habitat or as a platform for nutrient exchange for microorganisms. While $\mathrm{BC}$ has been appreciated for its chemical adsorption properties, Pietikainen et al. [58] reported that BC can support a habitat for the microbes. Furthermore, based on the chemical composition and physical structures that are prevalent in biochar particles, Thies and Rillig [59] have suggested that biochar has biological properties that are favorable to microbial communities. Residual hydrocarbons and materials adhering to the particle surface may directly support microbes. The idea that anthrosols may have distinct microbial populations is not new, but recently several facts have been demonstrated concerning the role of black carbon (BC) on the physical [60], chemical [61] and biological [58] processes in the anthrosols. The bacterial diversity of Amazonian Dark Earth is similar to pristine forest soil from the Western Amazon, but the richness in the ADE samples was increased by $25 \%$ [55].

When studying land conversion from tropical forest to agricultural use, several alterations may occur in the size, activity and composition of the microbial communities, as previously observed [27,62], and unusual microbial communities may prevail during shifts associated with deforestation [24,27]. These findings would be more relevant when studying ADE with high concentrations of $\mathrm{BC}$, as these particles are the oldest form of carbon in the soil [63].

A recent study surveyed the bacterial community composition in ADE and adjacent soils using culturing and molecular identification [57]. While the composition of unculturable bacteria was not directly assessed, sequences from 16S rRNA genes and their phylogenetic relationships were determined. Anthrosols contained high numbers of culturable bacteria, which were over two orders of magnitude higher at the deepest sampling depths than in adjacent soils. Overall, larger bacterial populations and a greater diversity of isolates were found in all four of the anthrosols studied, to a depth of up of $1 \mathrm{~m}$ compared to adjacent soils located within 50-500 m of the associated anthrosols. These data were the first indication that diverse soil microbial populations have adapted to the unique biochemistry and physiological ecology of these anthrosols. On the other hand, the archaeal community observed in ADE sites presented lower richness and diversity than the adjacent soil [64].

With the idea that the addition of $\mathrm{BC}$ to soil was due to fire events, these anthropic activities are thought to be determinant to the biogeochemistry of $\operatorname{ADE}[65,66]$, and they may alter the soil microbiological community structure and composition of the microbial communities below ground. Due to the prevalence of $\mathrm{BC}$ in $\mathrm{ADE}$ and its unique physical and chemical characteristics, more detailed studies were carried out to better understand the role of $\mathrm{BC}$ on the microbial populations in ADE soils.

In the Amazonian region, rapid turnover of the soil organic matter (OM) occurs due to the high temperatures and humidity typical of the tropics. These environmental extremes lead to increased turnover rates, with concomitant rapid depletion of the fragile nutrients of the adjacent unmodified soils compared relative to ADE. Therefore, the buffering capacity offered by BC, persisting over millennia, should also focus on its role as habitats or niche of soil microbial communities when tracing soil additives such as BC [67]. 


\subsubsection{The bacterial OTU richness of $\mathrm{ADE}$ and $\mathrm{BC}$}

The pyrosequencing data indicate that the $\mathrm{BC}$ can host species of Bacteria in numbers not much lower than the ADE; however, the latter had significantly greater OTU richness (Figure 4). On the other hand, as seen in Figure 4, of the total of OTU found in BC, 41\% were not present in the ADE soil, suggesting that this environment may be the host of specific processes. These data bring new perspectives regarding the opportunity for reconstruction of tropical and degraded soils by contemporary human activities.

Figure 4. Venn diagram of the operational taxonomic units (OTUs) based on the 16S rRNA gene analyzed by pyrosequencing (454 Roche). The diagram shows OTUs found exclusively in ADE (512), in black carbon (BC, 342) and the OTUs in held in common (492).

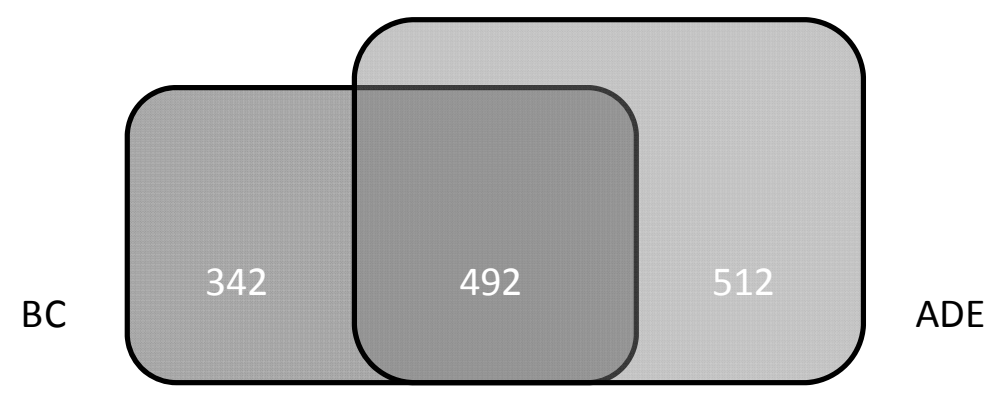

The numbers of species detected in a sample, or of the numbers of organisms discerned at any given phylogenetic level, are strongly affected by the number of sequences analyzed [68]. Estimates of OTUs increase with number of sequences and a plot of OTUs versus the number of sequences yields a rarefaction curve that approaches a maximum (Figure 5). To estimate the true maximum value at any phylogenetic level it is necessary to model and extrapolate from the rarefaction curve, or to use nonparametric methods to estimate the true OTU richness by taking into account the population structure. Based on 10,857 sequences, the values of richness estimations and heterogeneity indicated higher operational taxonomic units (OTUs) richness and diversity in ADE soils (1939.43 OTUs, $\left.H^{\prime}=6.23\right)$, followed by lower OTUs richness and diversity in libraries from BC (1586.06 OTUs, $\left.\mathrm{H}^{\prime}=5.93\right)$.

We recovered 10,857 partial sequences of the $16 \mathrm{~S}$ rRNA genes from $\mathrm{ADE}$ soil and $\mathrm{BC}$ of an average of 207 nucleotides in length. With over $24 \%$ of the total bacterial sequences, the Proteobacteria represented the dominant phylum in ADE soil, including representatives of the classes $\alpha, \beta, \gamma$ and $\delta$ of Proteobacteria (Figure 6). In contrast, Acidobacteria were a prominent phylum in BC with $21 \%$ of the bacterial sequences. The second most abundant phyla in ADE and BC were Acidobacteria (10\%) and Proteobacteria (15\%), respectively. Other prominent phyla in ADE were the Verrucomicrobia, Actinobacteria and the Planctomycetes, which represented $8 \%, 7 \%$ and $4 \%$ of total sequences, respectively. In $\mathrm{BC}$, the Actinobacteria were represented by more than $12 \%$ of the sequences. Among the other phyla, Verrucomicrobia (9\%) and Firmicutes (8\%) were found in BC. Approximately $26 \%-36 \%$ of the sequences from each sample remained unclassified. Tsai et al. [69] found higher abundance of Verrucomicrobia in ADE soil from Balbina site, located in the Central 
Amazon, than in ADJ of this same site. The distribution of verrucomicrobial rRNA in the soil reveals that Verrucomicrobia are significantly affected by environmental characteristics that change in relation to time, soil history, and soil depth, and reveals that a statistically significant amount of the variation in verrucomicrobial rRNA abundance can be explained by changes in soil moisture content [70].

Figure 5. Rarefaction curves of the Amazonian Dark Earth (ADE) and black carbon (BC). Sequences were obtained by pyrosequencing the bacterial $16 \mathrm{~S}$ rRNA gene pool from the ADE site at Hatahara in the Central Amazon.

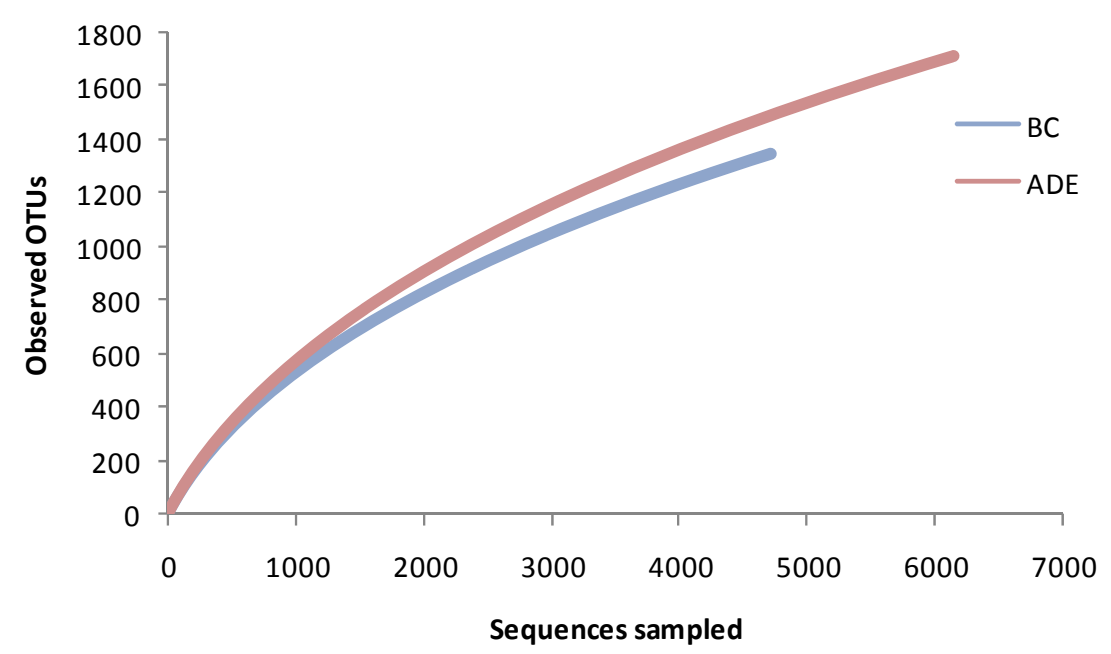

Phylogenetic analysis revealed differences in community composition linked to ADE soil and BC (Figure 6) and the clearest differences were found among the Acidobacteria, Proteobacteria, Actinobacteria and Firmicutes. Our results extend the understanding about the bacterial phyla present in ADE soil, such as those published by Kim et al. [55] and add information about the bacterial community composition in $\mathrm{BC}$, unknown until now. Our results obtained by pyrosequencing show higher numbers of bacterial phyla in $\mathrm{ADE}$ soil and $\mathrm{BC}$ in comparison with results obtained by Jesus et al. [27] using a clone library for the same soils considered in Model I. The additional bacterial phyla found in anthrosols were Chlamydiae, Nitrospira, OD1, TM7, BRC1, Planctomycetes and Verrucomicrobia. 
Figure 6. Relative abundance of phyla for $\mathrm{ADE}$ soil and $\mathrm{BC}$ pyrosequencing library, in which 16S rRNA gene sequences were classified according to the nearest neighbor in the Ribosomal Database Project (RDP-MSU, USA) pipeline.

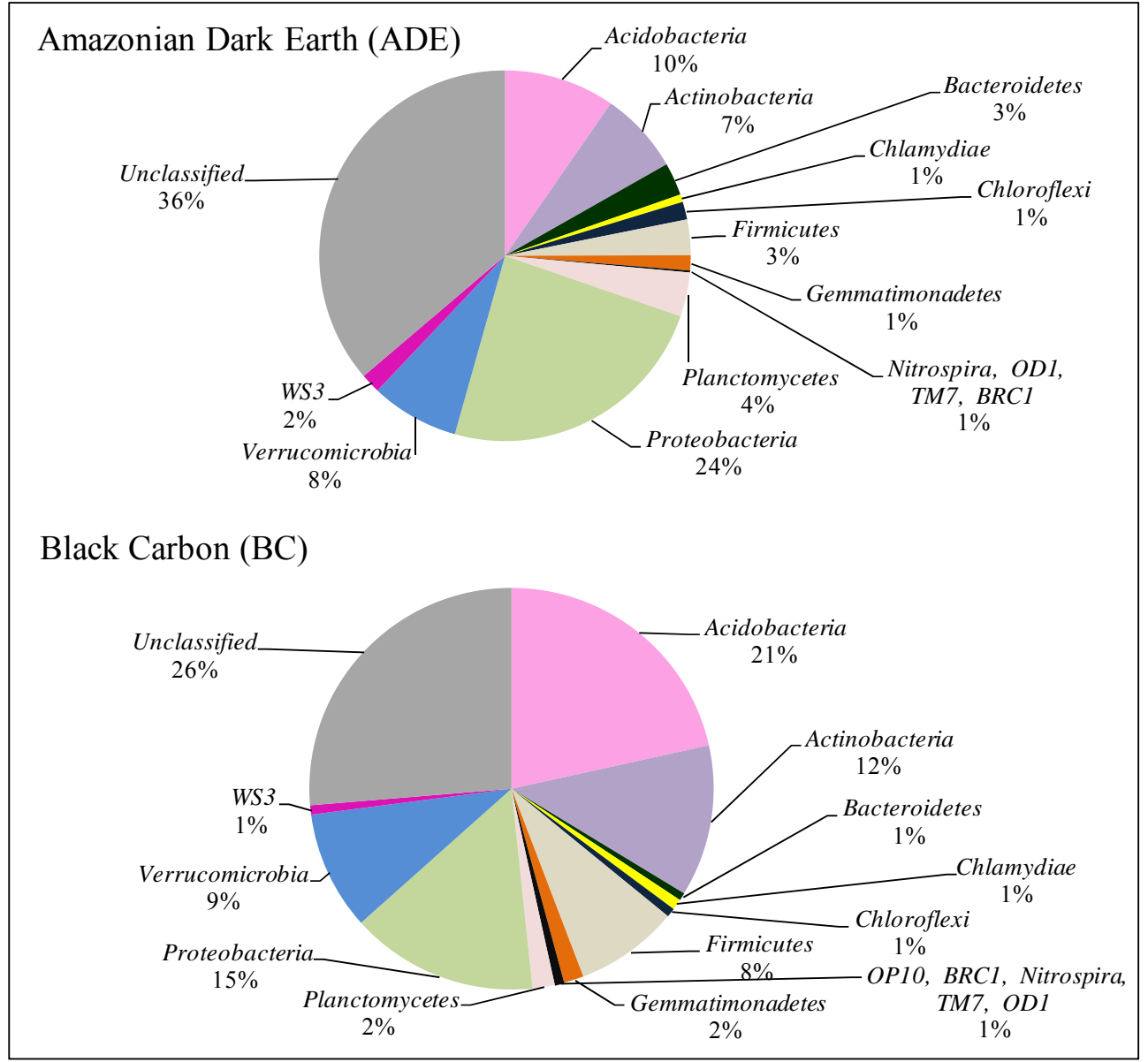

\section{Conclusions}

The molecular methods used to study the microbial communities in two agricultural systems that are practiced in Amazonia (the "slash-and-burn" system and the man-made anthrosols), based also upon the soil attributes, have enabled us to view a better but quite complex picture of the conditions of soil management by stakeholders or end-users who are looking to develop agricultural sustainability in tropical rain forest ecosystems without serious disturbance to these ecosystems.

Based on Model I ("slash-and-burn" system), both the traditional subsistence crop cultivation by indigenous people and the pasture made by nonindigenous people alter the structure of archaeal, bacterial and fungal communities in sites originally constituted by highland forests in Western Amazon. ARISA data evidenced considerable differences in the structures between microbial communities present in forest and those in agricultural soils. In this model, the re-growth of a secondary forest followed by agricultural practices provides evidence of an improved level of restoration when considering the organization of the soil microbial community structures.

On the basis of Model II (anthrosols-Amazonian Dark Earth), data revealed a higher T-RF number in ADE soil and an elevated T-RFs richness in BC by T-RFLP when using enzyme MspI. Differences were noted in the bacterial community composition in $\mathrm{ADE}$ soil and $\mathrm{BC}$, and a higher bacterial 
diversity present in anthrosols was revealed by pyrosequencing. In this model, the high fertility in the ADE associated with a higher soil bacterial diversity, even when under intensive cultivation by the native population, may contribute to the overall higher yields when compared to the lower crop productivities under the "slash-and-burn" agricultural system. The higher microbial diversity found in the Hatahara site, a well known anthrosol 1,500 years old [71], highlights the importance of anthrosols to the sustainability of the Amazonian soils for crop production.

\section{Acknowledgements}

The group would like to sincerely express their thanks and gratitude to $\mathrm{CNPq}$ - Conselho Nacional de Pesquisa e Desenvolvimento Tecnológico (project $N^{\circ}$ 474455/2007-6), FAPESP_Fundação de Amparo à Pesquisa do Estado de São Paulo (project No 2006/06700-0) and GEF/UNEP_Global Environmental Facility/United Nations Environment Program (project CSM-BGBD/GF2715-02) for the financial support. We also would like to thank the fellowships given by FAPESP and CNPq. The group also is in debt to James Tiedje and Ederson C. Jesus (Center of Microbial Ecology-Michigan State University, MI, USA) for the DNA pyrosequencing support and to José E. Gomes and Fábio R.S. Duarte for their assistance on the molecular analyses.

\section{References}

1. Fearnside, P.M. Uso da terra na Amazônia e as mudanças climáticas globais. Braz. J. Ecol. 2006, 7, 83-100.

2. Nye, P.H.; Greenland, D.J. The soils under shifting cultivation. Commonwealth Bureau Soils, Tech. Comm. Harpenden, UK, 1960, No. 51.

3. Sanchez, P.A; Buol, S.W. Soils in the tropics and world food crisis. Science 1975, 188, 598-603.

4. Barrow, C.J. Land Degradation; Cambridge University Press: Cambridge/London/New York, 1991.

5. Juo, A.S.; Manu, R.A. Chemical dynamics in slash-and-burn agriculture. Agricult. Ecosys. Environ. 1996, 58, 49-60.

6. Fidalgo, E.C.C.; Coelho, M.R.; Araujo, F.O.; Moreira, F.M.S.; Santos, H.G.; Brefin, M.L.M.S.; Huising, J. Levantamento do uso e cobertura da terra de seis áreas amostrais relacionadas ao projeto BiosBrasil (Conservation and Sustainable Management of Below-Groud Biodiversity: Phase I), Município de Benjamin Constant (AM). Rio de Janeiro: Embrapa Solos, 2005. (Boletim De Pesquisa E Desenvolvimento/Embrapa Solos, ISSN 1678-0892; 71).

7. Lehmann, J.; Kern, D.C.; German, L.; McCann, J.; Martins, G.C.; Moreira, A. Soil fertilityand production potential. In Amazonian Dark Earths: Origin, Properties, Management; Lehmann, J., Kern, D.C., Glaser, B., Woods, W.I., Eds.; Kluwer Academic Publishers: Dordrecht, The Netherlands, 2003; pp. 105-124.

8. Marris, E. Putting the carbon back: Black is the new green. Nature 2006, 442, 624-626.

9. Woods, W.I. Development of anthrosol research. In Amazonian Dark Earths: Origin, Properties, and Management; Lehmann, J., Kern, D.C., Glaser, B., Woods, W.I., Eds.; Kluwer Academic Publishers: Dordrecht, The Netherlands, 2003; pp. 3-14. 
10. Coelho, M.R.; Fidalgo, E.C.C.; Araújo, F.O.; dos Santos, H.G.; Mendonça, S.M.L.; Pérez, D.V.; Moreira, F.M.S. 2005. Solos das áreas-piloto do Projeto BiosBrasil (Conservation and Sustainable Management of Below Ground Biodiversity: Phase I), Município de Benjamim Constant, Estado do Amazonas [recurso eletrônico] Rio de Janeiro: Embrapa Solos. (Boletim de pesquisa e desenvolvimento/Embrapa Solos, ISSN 1678-0892; 67).

11. Bentivenga, S.P.; Morton, J.B. Stability and heritability of fatty acid methyl ester profiles of glomalean endomycorrhizal fungi. Mycolog. Res. 1994, 98, 1419-1426.

12. Garcia-Martínez, J.; Rodriguez-Valera, F. Microdiversity of uncultured marine prokaryotes: the SAR11 cluster and the marine Archaea of group I. Molecular Ecol. 2000, 9, 935-948.

13. Casamayor, E.O.; Massana, R.; Benlloch, S.; Øvreas, L.; Díez, B.; Goddard, V.J.; Gasol, J.M.; Joint, G.I.; Rodríguez-Valera, F.; Pedrós-Alió, C. Changes in archaeal, bacterial and eukaryal assemblages along a salinity gradient by comparison of genetic fingerprinting methods in a multipond solar saltern. Env. Microbiol. 2002, 4, 338-348.

14. Sequerra, J.; Marmeisse, R.; Valla, G.; Normand, P.; Capellano, A.; Moiroud, A. Taxonomic position and intraspecific variability of the nodule forming Penicillium nodositatum inferred from RFLP analysis of the ribosomal intergenic spacer and random amplified polymorphic DNA. Mycolog. Res. 1997, 101, 465-472.

15. Peres-Neto, P.R.; Legendre, P.; Dray, S.; Borcard, D. Variation partitioning of species data matrices: estimation and comparison of fractions. Ecology 2006, 87, 2614-2625.

16. Edwards, U.; Rogall, T.; Blocker, H.; Emde, M.; Bottger, E.C. Isolation and direct complete nucleotide determination of entire genes. Characterization of a gene coding for $16 \mathrm{~S}$ ribosomal RNA. Nucleic Acids Res. 1989, 17, 7843-7853.

17. Woese, C.R.; Kandler, O.; Wheelis, L. Towards a natural system of organisms: proposal for the domains Archaea, Bacteria and Eucarya. Proc. Nat. Acad. Sci. USA 1990, 87, 4576-4579.

18. Sambrook, J.; Russell, D.W. Molecular Cloning: A Laboratory Manual, 3rd ed.; Cold Spring Harbor Laboratory Press: New York, NY, USA, 2001.

19. Kindt, R.; Coe, R.; Tree Diversity Analysis. A Manual and Software for Common Statistical Methods and Biodiversity Studies. World Agroforestry Centre (ICRAF): Nairobi, Kenya, 2005.

20. R Development Core Team. R: A language and environment for statistical computing. R Foundation for Statistical Computing, Vienna, Austria. 2007. ISBN 3-900051-07-0. Available online: http://www.R-project.org (accessed May 2010).

21. Wang, Q. Artificial neural networks as cost engineering methods in a collaborative manufacturing environment. Int. J. Prod. Econ. 2007, 109, 53-64.

22. Cole, J.R.; Wang, Q.; Cardenas, E.; Fish, J.; Chai, B.; Farris, R.J.; Kulam-Syed-Mohideen, A.S.; McGarrell, D.M.; Marsh, T.; Garrity, G.M; Tiedje, J.M. The Ribosomal Database Project: improved alignments and new tools for rRNA analysis. Nucleic Acids Res. 2009, 37, 141-145.

23. Schloss, P.D.; Westcott, S.L.; Ryabin, T.; Hall, J.R.; Hartmann, M.; Hollister, E.B.; Lesniewski, R.A.; Oakley, B.B.; Parks, D.H.; Robinson, C.J.; Sahl, J.W.; Stres, B.; Thallinger, G.G.; Van Horn, D.J.; Weber, C.F. Introducing mothur: open-source, platform-independent, communitysupported software for describing and comparing microbial communities. Appl. Environ. Microbiol. 2009, 75, 7537-7541. 
24. Borneman, J.; Triplett, E.W. Molecular microbial diversity in soils from Eastern Amazonia: evidence for unusual microorganisms and microbial population shifts associated with deforestation. Appl. Environ. Microbiol. 1997, 63, 2647-2653.

25. Donovan, S.E.; Purdy, K.J.; Kane, M.D.; Eggleton, P. Comparison of Euryarchaea strains in the guts and food-soil of the soil-feeding termite Cubitermes fungifaber across different soil types. Appl. Environ. Microbiol. 2004, 70, 3884-3892.

26. Winter, C.; Smit, A.; Herndl, G.J.; Weinbauer, M.G. Impact of virioplankton on archaeal and bacterial community richness as assessed in seawater batch cultures. Appl. Environ. Microbiol. 2004, 70, 804-813.

27. Jesus, E.C.; Marsh, T.L.; Tiedje, J.M.; Moreira, F.M.S. Changes in land use alter the structure of bacterial communities in Western Amazon soils. ISME J. 2009, 3, 1004-1011.

28. Rambelli, A.; Persiani, A.M.; Maggi, O.; Lunghini, D.; Onofri, S.; Riess, S.; Dowgiallo, G.; Puppi, G. Comparative studies on microfungi in tropical ecosystems. Mycological studies in South Western Ivory Coast forest. Report no. 1, MAB, UNESCO, 1983, p. 102.

29. Rambelli, A.; Persiani, A.M.; Maggi, O.; Onofri, S.; Riess, S.; Dowgiallo, G.; Zucconi, L. Further mycological studies in south western Ivory Coast forest. Report no. 2, Giornale Botanici Italica 1984, 118, 201-243.

30. Maggi, O.; Persiani, A.M.; Casado, M.A.; Pineda, F.D. Edaphic mycoflora recovery in tropical forests after shifting cultivation. Acta Oecologica 1990, 11, 337-350.

31. Persiani, A.M.; Maggi, O.; Casado, M.A.; Pineda, F.D. Diversity and variability in soil fungi from a disturbed tropical rain forest. Mycologia 1998, 90, 206-214.

32. Antoniolli, Z.I.; Schachtman, D.P.; Ophel-Keller, K.; Smith, S.E. Variation in rDNA ITS sequences in Glomus mosseae and Gigaspora margarita spores from a permanent pasture. Mycol. Res. 2000, 104, 708-715.

33. Piccolo, M.C.; Neill, C.; Cerri, C.C. Natural abundance of $15 \mathrm{~N}$ in soils along forest-to-pasture chronosequences in the western Brazilian Amazon Basin. Oecologia 1994, 99, 112-117.

34. Reiners, W.A.; Bouwman, A.F.; Parsons, W.F.J.; Keller, M. Tropical rain forest conversion to pasture: changes in vegetation and soil properties. Ecol. Appl. 1994, 4, 363-377.

35. Moraes, J.F.L.; Neill, C.; Volkoff, B.; Cerri, C.C.; Melillo, J.; Lima, V.C.; Steudler, P.A. Soil carbon and nitrogen stocks following forest conversion to pasture in the Western Brazilian Amazon Basin. Acta Scientiarum 2002, 24, 1369-1376.

36. Bünemann, E.K.; Marschner, P.; Smernik, R.J.; Conyers, M.; McNeill, A.M. Soil organic phosphorus and microbial community composition as affected by 26 years of different management strategies. Biol. Fertil. Soils 2008, 44, 717-726.

37. Makarov, M.I.; Haumaier, L.; Zech, W.; Marfenina, O.E.; Lysak, L.V. Can 31P NMR spectroscopy be used to indicate the origins of soil organic phosphates? Soil Biol. Biochem. 2005, 37, 15-25.

38. Buckley, D.H.; Schmidt, T.M. Diversity and dynamics of microbial communities in soils from agro-ecosystems. Environ. Microbiol. 2003, 5, 441-452.

39. Bending, G.D.; Turner, M.K.; Jones, J.E. Interactions between crop residue and soil organic matter quality and the functional diversity of soil microbial communities. Soil Biol. Biochem. 2000, 34, 1073-1082. 
40. Bossio, D.A.; Scow, K.M. Impacts of carbon and flooding on soil microbial communities: phospholipid fatty acid profiles and substrate utilization patterns. Microb. Ecol. 1998, 35, 265-278.

41. Bulluck, L.R.; Ristaino, J.B. Effect of synthetic and organic soil fertility amendments on southern blight soil microbial communities and yield of processing tomatoes. Phytopathology 2002, 92, 181-189.

42. de Brito Alvarez, M.A.; Gagne, S.; Antoun, H. Effect of compost on rhizosphere microflora of the tomato and on the incidence of plant-growth promoting rhizobacteria. Appl. Environ. Microbiol. 1995, 61, 194-199

43. Degens, B.P.; Schipper, L.A.; Sparling, G.P.; Duncan, L.C. Is the microbial community in a soil with reduced catabolic diversity less resistant to stress or disturbance? Soil Biol. Biochem. 2001, 33, 1143-1153.

44. Lupwayi, N.Z.; Rice, W.A.; Clayton, G.W. Soil microbial diversity and community structure under wheat as influenced by tillage and crop rotation. Soil Biol. Biochem. 1998, 30, 1733-1741.

45. Steenwerth, K.L.; Jackson, L.E.; Calderón, F.J.; Stromberg, M.R.; Scow, K.M. Soil microbial community composition and land use history in cultivated and grassland ecosystems of coastal California. Soil Biol. Biochem. 2003, 35, 489-500.

46. Fisher, M.M.; Triplett, E. Automated approach for ribosomal intergenic spacer analysis of microbial diversity and its application to freshwater bacterial communities. Appl. Environ. Microbiol. 1999, 65, 4630-4636.

47. Ranjard, L.; Poly, F.; Lata, J-C.; Mougel, C.; Thioulouse, J.; Nazaret, S. Characterization of bacterial and fungal soil communities by automated ribosomal intergenic spacer analysis fingerprints: biological and methodological variability. Appl. Environ. Microbiol. 2001, 67, 4479-4487.

48. Saison, C.; Degrange, V.; Oliver, R.; Millard, P; Commeaux, C.; Montange, D.; Roux, X.L. Alternation and resilience of the soil microbial community following compost amendment: effects of compost level and compost-borne microbial community. Environ. Microbiol. 2006, 8, 247-257.

49. Wu, T.; Chellemi, D.O.; Graham, J.H.; Martin, K.J.; Rosskopf, E.N. Comparison of soil bacterial communities under diverse agricultural land management and crop production practices. Microb. Ecol. 2008, 55, 293-310.

50. Lima, H.N.; Schaefer, C.E.R.; Mello, J.W.V.; Gilkes, R.J.; Ker, J.C. Pedogenesis and preColumbian land use of "Terra Preta Anthrosols" ("Indian black earth") of Western Amazonia. Geoderma 2002, 110, 1-17.

51. Falcão, N.P.S.; Borges, L.F. Efeito da fertilidade de terra preta de índio da Amazônia Central no estado nutricional e na produtividade do mamão hawaí (Carica papaya L.). Acta Amazônica 2006, 36, 401-406.

52. Lehmann, J.; Silva, J.P.; Steiner, C.; Nehls, T.; Zech, W.; Glaser, B. Nutrient availability and leaching in an archaeological Anthrosol and a Ferralsol of the Central Amazon basin: Fertilizer, manure and charcoal amendments. Plant Soil 2003, 249, 343-357.

53. Liang, B.; Lehmann , J.; Solomon, D.; Kinyangi J.; Grossman, J.; O’Neill, B.; Skjemstad, O.; Thies, J.; Luizão, F.J.; Petersen, J.; Neves, E.G. 2006. Black carbon increases cation exchange capacity in soils. Soil Sci. Soc. Am. J. 2006, 70, 1719-1730. 
54. Glaser, B.; Lehmann, J.; Zech, W. Ameliorating physical and chemical properties of highly weathered soils in the tropics with charcoal-a review. Biol. Fertil. Soils 2002, 35, 219-230.

55. Kim, J.S.; Sparovek, G.; Longo, R.M.; De Melo, W.J.; Crowley, D. Bacterial diversity of terra preta and pristine forest soil from the Western Amazon. Soil Bio. Biochem. 2007, 39, 684-690.

56. O’Neill, B.; Grossman, J.; Tsai, S.M.; Gomes, J.E.; Lehmann, J.; Peterson, J.; Neves, E.; Thies, J.E. Bacterial community composition in Brazilian anthrosols and adjacent soils characterized using culturing and molecular identification. Microb. Ecol. 2009, 58, 23-35.

57. Glaser, B. Prehistorically modified soils of central Amazonia: a model for sustainable agriculture in the twenty-first century. Phil. Trans. R. Soc. B 2007, 362, 187-196.

58. Pietikainen, J.; Kiikkila, O.; Fritze, H. Charcoal as a habitat for microbes and its effect on the microbial community of the underlying humus. Oikos 2000, 89, 231-242.

59. Thies, J.E.; Rillig, M.C. Characteristics of biochar: Biological properties. In Biochar for Environmental Management; Lehmann, J., Joseph, S., Eds.; Earthscan, Dunstan House: London, UK, 2008.

60. Warnock, D.D.; Lehmann, J.; Kuyper, T.W.; Rillig, M.C. Mycorrhizal responses to biochar in soil—concepts and mechanisms. Plant Soil 2007, 300, 9-20.

61. Liang, B.; Lehmann, J.; Solomon, D.; Kinyangi, J.; Grossman, J.; O’Neill, B.; Skejmstad, J.O.; Thies, J.; Luizao, F.J.; Petersen, J.; Neves, E.G. Black Carbon increases cation exchange capacity in soils. Soil Sci. Soc. Am. J. 2006, 70, 1719-1730.

62. Nusslein, K.; Tiedje, J.M. Soil bacterial community shift correlated with change from forest to pasture vegetation in a tropical soil. Appl. Environ. Microb. 1999, 65, 3622-3626.

63. Pessenda, L.C.R.; Gouveia, S.E.M.; Aravena, R. Radiocarbon dating of total soil organic matter and humin fraction and its comparison with C-14 ages of fossil charcoal. Radiocarbon 2001, 43, 595-601.

64. Taketani, R.G.; Tsai, S.M. The influence of different land uses on the structure of archaeal communities in Amazonian anthrosols based on 16S rRNA and amoA genes. Microb. Ecol. 2010, DOI: $10.1007 / \mathrm{s} 00248-010-9638-1$.

65. Glaser, B.; Guggenberger, G.; Zech, W. Organic chemistry studies on Amazonian Dark Earths. In Amazonian Dark Earths: Origin, Properties, and Management; Lehmann, J., Kern, D., Glaser, B., Woods, W., Eds.; Kluwer: Dordrecht, The Netherlands, 2003; pp. 227-241.

66. Glaser, B.; Guggenberger, G.; Zech, W.; Ruivo, M.L. Soil organic matter stability in Amazonian Dark Earths. In Amazonian Dark Earths: Origin, Properties, and Management; Lehmann J., Kern D., Glaser B., Woods W., Eds.; Kluwer: Dordrecht, The Netherlands, 2003; pp. 141-158.

67. Lehmann, J.; Liang, B.; Solomon, D.; Lerotic, M.; Luizao, F.; Kinyangi, J.; Schafer, T.; Wirick, S.; Jacobsen, C. Near-edge X-ray absorptive fine structure (NEXAFS) spectroscopy for mapping nano-scale distributions of organic carbon forms in soil: application to .black carbon particles. Glob Biogeochem. Cycles 2005, 19, 1-12.

68. Schloss, P.D.; Handelsman, J. Introducing DOTUR, a computer program for defining operational taxonomic units and estimating species richness. Appl. Environ. Microbiol. 2005, 71, 1501-1506.

69. Tsai, S.M.; O’Neill, B.; Cannavan, F.S.; Saito, D.; Falcão, N.P.S.; Kern, D.; Grossman, J.; Thies, J. Microbial World of Terra Preta. In Terra Preta Nova: A Tribute to Wim Sombroek, 1st ed.; Woods, W.I., Ed.; Springer Verlag: New York, NY, USA, 2008; volume 1, pp. 299-308. 
70. Buckley, D.H.; Schmidt, T.M. Environmental factors infuencing the distribution of rRNA from Verrucomicrobia in soil. FEMS Microbiol. Ecol. 2001, 35, 105-112.

71. Neves, E.G.; Petersen, J.B.; Bartone, R.N.; Silva, C.A. Historical and socio-cultural origins of Amazonian Dark Earths. In Amazonian Dark Earths: Origin, Properties, and Management; Lehmann, J., Kern, D., Glaser, B., Woods, W., Eds.; Kluwer: Dordrecht, The Netherlands, 2003; pp. 3-14.

(C) 2010 by the authors; licensee MDPI, Basel, Switzerland. This article is an Open Access article distributed under the terms and conditions of the Creative Commons Attribution license (http://creativecommons.org/licenses/by/3.0/). 